U. S. DEPARTMENT OF COMMERCE BUREAU OF STANDARDS

\title{
COLORS FOR SANITARY WARE
}

COMMERCIAL STANDARD CS30-31

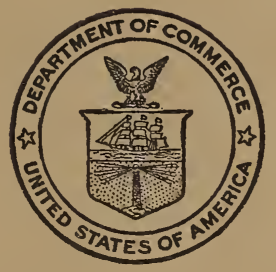

A RECORDED STANDARD OF THE INDUSTRY 
Below are described some of the series of publications of the Department of Commerce which deal with various phases of waste elimination.

\section{Simplified Practice Recommendations.}

These present in detail the development of programs to eliminate unnecessary variety in sizes, dimensions, styles, and types of over 120 commodities. They also contain lists of associations and individuals who have indicated their intention to adhere to the recommendations. These simplified schedules, as formulated and approved by the industries, are indorsed by the Department of Commerce.

\section{American Marine Standards.}

These are promulgated by the American Marine Standards Committee, which is controlled by the marine industry and administered as a unit of the division of simplified practice. Their object is to promote economy in construction, equipment, maintenance, and operation of ships. In general, they provide for simplification and improvement of design, interchangeability of parts, and minimum requisites of quality for efficient and safe operation.

\section{Commercial Standards.}

These are developed by various industries under a procedure similar to that of simplified practice recommendations. They are, however, primarily concerned with considerations of grade, quality, and such other characteristics as are outside the scope of dimensional simplification.

Lists of the publications in each of the above series can be obtained by applying to the National Bureau of Standards, Washington, D. C. 


\section{U. S. DEPARTMENT OF COMMERCE}

R. P. LAMONT, Secretary

BUREAU OF STANDARDS

GEORGE K. BURGESS, Director

\section{COLORS FOR SANITARY WARE}

\section{COMMERCIAL STANDARD CS30-31}

[Issued January 20, 1932]

Effective Date for New Production and Clearance of Existing Stocks July 1, 1931

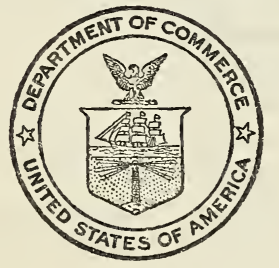

UNITED STATES

GOVERNMENT PRINTING OFFICE

WASHINGTON : 1932

For sale by the Superintendent of Documents, Washington, D. C. - - Price 20 cents 


\section{CONTENTS}

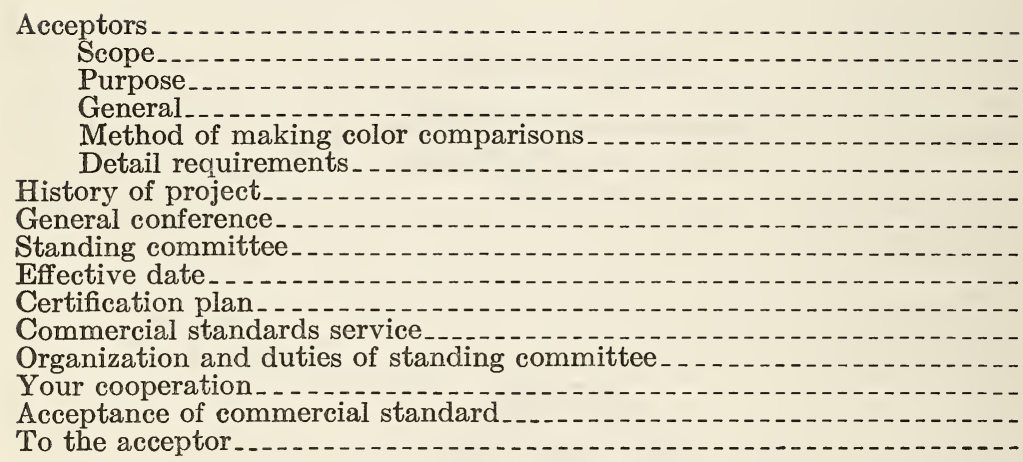

Acceptance of commercial standard 


\section{COLORS FOR SANITARY WARE, CS 30-31}

\section{ACCEPTORS}

\section{ASSOCIATIONS}

American Electric Railway Association, New York, N. Y. (in principle).

American Warehousemen's Association, merchandise division, Chicago, Ill.

Architects League of Northern New Jersey, The, Cliffside Park, N. J.

Eastern Supply Association, New York, N. Y. (in principle).

Illinois Master Plumbers' Association, Chicago Heights, Ill.

National Association of Master Plumbers of the U. S. (Inc.), New York, $\mathrm{N}$. Y. (in principle).

National Association of Master Plumbers, Washington, D. C.

National Electrical Manufacturers Association, refrigeration division, New York, N. Y. (in principle).

New England Council, Boston, Mass. (in principle).

San Diego Merchant Plumbers Association, San Diego, Calif.

Title \& Mantel Contractors' Association of America, Washington, D. C.

\section{FIRMS}

Abingdon Sanitary Manufacturing Co., Abingdon, Ill.

Adkins, Young \& Allen Co., Chicago, Ill. (in principle).

Ahlbach \& Mayer, San Francisco, Calif. Alliance Vitrified China Co., The, Alliance, Ohio.

America Heating \& Supply Co., Rockford, Ill.

Anderson, D. E., Marquette, Mich.

Atchison, William J., Whitmire, S. C. (in principle).

Bailey-Lebby Co., The, Charleston, S. C.

Baker Plumbing Co. (Inc.), Beaumont, Tex.

Barger Heating \& Plumbing Co., Princeton, W. Va.

Barnes Manufacturing Co., Mansfield, Ohio.

Basche Sage Hardware Co., Baker, Oreg.

Beaver Refrigerator \& Potteries Co., New Brighton, Pa. (in principle).

Behrer \& Co. (Inc.), New York, N. Y.
Belknap Hardware \& Manufacturing Co., Louisville, $\mathrm{Ky}$.

Berger \& Bro., Edward W., Weehawken, N. J.

Berkshire Sanitary Supply Co., Pittsfield, Mass.

Bethlehem Plumbing Supply Co., Bethlehem, $\mathrm{Pa}$.

Biggs Pump \& Supply Co., Lafayette, Ind.

Blackwell-Wielandy Co., St. Louis, Mo. Blake-Rounds Supply Co., Portland, Me.

Blodgett Supply Co. (Inc.), The, Plattsburg, N. Y.

Blodgett Supply Co. (Inc.), The, Burlington, Vt.

Bond Co. (Inc.), W. H., Raleigh, N. C. Boosey Manufacturing Co., Norman, Detroit, Mich. (in principle)

B. O. T. Manufacturing Co., Trenton, N.J.

Boyd Plumbing Supply Co. (Inc.), Newark, N. J.

Bradley Co., J. R., Reno, Nev.

Bradley Supply Co., Chicago, Ill.

Braman, Dow \& Co., Boston, Mass.

Brass City Plumbing Supply Co., Waterbury, Conn.

BRE Manufacturing Co., Hyde Park, Mass.

Bridgeport Plumbing Supply Co. (Inc.), Bridgeport, Conn.

Bumsteads, Heating \& Plumbing, Colorado Springs, Colo.

Bushnell Pump Co., Bushnell, Ill.

Callis, jr., George R., Catonsville, Md.

Camlet, J. Thomas, Clifton, N. J.

Canfield Supply Co., Kingston, N. Y.

Careva Co. (Inc.), The, York, Pa.

Carl's Sheet Metal Works, Charleston, S. C.

Case \& Son Manufacturing Co., W. A. Buffalo, N. Y.

Cedar Rapids Pump \& Supply Co., Cedar Rapids, Iowa.

Central Metal \& Supply Co., Baltimore, Md.

Central Plumbing Supply Co., Bridgeport, Conn.

Central Supply Co., Minneapolis, Minn.

Ceramic Color \& Chemical Manufacturing Co., New Brighton, Pa. 
Chandler Pump Co., Cedar Rapids, Iowra.

Channel Co., Jong Beach, Calif.

Chapman Co., The, Detroit, Mich.

Chicago Pottery Co., Chicago, Ill.

Christman-Lansing Co., H. G., Lansing, Mich.

Church Manufacturing Co., C. F., Holyoke, Mass.

City of Detroit, Department of Water Supply, Dearborn, Mich.

Clinton Plumbing Surpply Co. (Inc.), Union City, N.J.

Cochran-Sargent Co., St. Paul, Minn.

Cole Supply Co. (Inc.), George H., Troy, N. Y.

Conemaugh Iron Works, Latrobe, Pa.

Cooper Supply Co., Harry, Springfield, Mo.

Coyne \& Delany Co., Brooklyn, N. Y.

Dahn (Inc.), Edward, Philadelphia, Pa.

Dalton Supply Co., Clarks Summit, Pa.

Dalziel Moller Co., San Francisco, Calif.

Depue, C. J., Towanda, Pa.

Dericks, John H., Passaic, N. J.

Desco Corporation, Wilmington, Del.

Detroit Lead Pipe Works, Detroit, Mich.

Deutz \& Bro., A., Laredo, Tex.

Diamond Match Co., The, Oswego, N. Y.

Dimock \& Fink Co. of Stamford Connecticut, Stamford, Conn.

Dimock \& Fink Co., New York, N. Y.

Douglas Co., The John, Cincinnati, Ohio.

Drake (Inc.), George H., Buffalo, N. Y.

Drakenfeld \& Co. (Inc.), B. F., New York, N. Y. (in principle).

Dubuque Supply Co., R. A., St. Louis, Mo.

Egyptian Supply Co., Christopher, Ill.

Egyptian Supply Co., Paducah, Ky.

Endicott Co., Philadelphia, Pa.

Fall River Steam \& Gas Pipe Co. Corporation, Fall River, Mass.

Fell, A., Mount Vernon, N. Y. (in principle).

Field \& Shorb Co., The, Decatur, Ill.

Fleck Bros. Co., Philadelphia, Pa.

Flint Faience \& Tile Co., Flint, Mich. (in principle).

Florida Automobile \& Gas Engine Co., Tampa, Fla.

Ford's Porcelain Works, Perth Amboy, N. J.

Franklin Potêery (Inc.), Lansdale, Pa.

Frazer, Guy Lewis, El Paso, Tex.

Frontier Water \& Steam Supply Co., Buffalo, N. Y. (in principle).

Galloup Pipe \& Supply Co., Battle Creek, Mich.

Gardner, H. Sumner, Binghamten, N. Y.
Geddes Co., Henry B., West Orange, N. J.

Gehri Heating \& Plumbing Co., Tacoma, Wash.

General Ceramics Co., New York, N. Y.

Globe Machinery \& Supply Co., Des Moines, Iowa.

Grey Libbey Co., The F., Hartford, Conn. (in principle).

Grubb, H. D., Lexington, Ill.

Gustaveson, Harry, New York, N. Y.

Hall \& Knight Hardware Co., Lewiston, Me. (in principle).

Harris Pump \& Supply Co., Pittsburgh, $\mathrm{Pa}$.

Hayden Supply Co., Grand Rapids, Mich.

Hazleton Machinery \& Supply Co. (Inc.), Hazleton, Pa.

Healey Pottery Co., Trenton, N. J.

Heap \& Sons, William, Grand Haven, Mich.

Hermitage Engineering Co., Nashville, Tenn.

Hess Co., Charles, New York, N. Y.

Higbro Engineering Co., Wellington, Kans.

Hillman Plumbing Co., McCamey, Tex. (in principle).

Hoffmann \& Billings Manufacturing Co., Milwaukee, Wis.

Hoggson Bros. (Inc.), New York, N. Y

Holyoke Supply Co. (Inc.), Holyoke, Mass.

Honeywell \& Co., C. F., Oakland, Calif.

Howard Plumbing Supply Co., Newark, N. J.

Howe Supply Co., W. B., St. Joseph, Mo.

Hubbard Co., The S. B., Jacksonville, Fla.

Hughes Supply Co., The, Mansfield, Ohio.

Humphryes Manufacturing Co., The, Mansfield, Ohio.

Hunter \& Co., Alfred J., Muskegon, Mich.

Hunting Supply Corporation, Watertown, N. Y.

Hussey \& Son (Inc.), W. H., New York, N. Y.

Ideal Supply Co., Somerville, Mass. Ihler, J. P., Spokane, Wash.

Inland Pipe \& Supply Co., Yakima, Wash.

Interstate Hardware \& Supply Co., Bristol, Va.

Iron City Sanitary Manufacturing Co., Pittsburgh, Pa.

Jahns Supply Co., Fort Worth, Tex. Johnson-Barker Co., Nashua, N. H.

Johnson, G. W., Berwick, Pa.

Johnson, Roscoe A., Portland, Oreg.

Kalispell Mercantile Co., Kalispell, Mont. 
Kansas City Pump Co., Kansas City, Mo.

Keating Co., E. F., New York, N. Y.

Keiser-Van Leer Co., The, Bloomington, Ill.

Keith Simmons Co. (Inc.), Nashville, Tenn.

Kensington Plumbing Supply Co., Philadelphia, Pa.

Killzun (Inc.), Chicago, Ill.

Kimble Glass Co., Vineland, N. J.

Kinsey \& Mahler Co., Peoria, Ill.

Kinsey Co., H. P., Easton, Pa.

Klink \& Co., N. S., Phoenix, Ariz.

Klotsch \& Appel (Inc.), Baltimore, Md.

Knapp Supply Co., The, Muncie, Ind.

Kokomo Supply Co., Kokomo, Ind.

Kretschmer-Tredway Co., Dubuque, Iowa.

Kuhns Bros. Co., Dayton, Ohio (in principle).

Laib Co. (Inc.), Norwood, Ohio.

Lansdown Machine Works, Walsenburg, Colo.

Larsen \& Son, G. A., Chicago, Ill.

Leighton Supply Co., Fort Dodge, Iowa.

Leonard Refrigerator Co., Kelvinator Corporation, Detroit, Mich. (in principle).

Levine, Samuel, New York, N. Y.

Link Co., The, Jackson, Mich.

Ludington (Inc.), E. A., New Rochelle, N. Y.

Lyon (Inc.), A. E., Glendale, Calif. (in principle).

Malone Plumbing Supply Co., Pittsburgh, $\mathrm{Pa}$.

Marshall Wells Co., Seattle, Wash.

Martin Metal Manufacturing Co., The, Wichita, Kans.

May Co., Galesburg, Ill.

May Supply Co., Anderson, Ind.

McArdle \& Cooney (Inc.), Philadelphia, $\mathrm{Pa}$.

McAuliffe \& Burke Co., Boston, Mass.

McKenna, James H., Savannah, Ga.

McNeilly Mantel \& Tiling Co., McKeesport, $\mathrm{Pa}$.

Mercedes Plumbing Co., Mercedes, Tex.

Merkel Bros. Co., The, Cincinnati, Ohio.

Messer \& Co. (Inc.), James A., Washington, D. C

Michigan Porcelain Tile Works, Ionia, Mich.

Michigan Supply Co., Lansing, Mich.

Miller \& Yeager, Terre Haute, Ind.

Miller Supply Co., Chicago, IIl.

Milwaukee Plumbing \& Heating Supply Co., Milwaukee, Wis.

Missoula Mercantile Co., Missoula, Mont.

Mohican Pottery Co., Philadelphia, Pa.

Mott Co., J. L., Trenton, N. J.

Mueller Co., Decatur, Ill.

Murdock Manufacturing \& Supply Co., The, Cincinnati, Ohio.
Murray \& Sorensen (Inc.), New York, N. Yे.

Murray, Harris M., Port Chester, N. Y.

Nailon Corporation, Peoria, Ill.

National-Helfrich Potteries Co., Evansville, Ind.

National Mill Supply Co., Fort Wayne, Ind.

National Tile Co., The, Anderson, Ind. (in principle).

Nelson Co., Detroit, Mich.

Nelson Manufacturing Co., N. O., St. Louis, Mo.

Never-Split Seat Co., Evansville, Ind.

New Freedom Hardware Co., New Freedom, Pa.

New Jersey Engineering \& Supply Co., Passiac, N. J.

New Kensington Sanitary Pottery (Inc.), New Kensington, $\mathrm{Pa}$. (in principle).

Norfolk \& Western Railway Co., Roanoke, Va.

O'Connell, J. T., Newport, R. I.

Oehrle, William, New York, N. Y.

O'Keefe \& Merritt Co., Los Angeles, Calif.

Olsen \& Heffernan, San Francisco, Calif.

Oregon Short Line R. R. Co., Salt Lake City, Utah.

Pancoast Co., Henry B., Philadelphia, $\mathrm{Pa}$.

Pattison Supply Co., The W. M., Cleveland, Ohio.

Peck Co., Frank B., Hornell, N. Y.

Peerless-Tulsa Co., Tulsa, Okla.

Peerless Utah Co., Salt Lake City, Utah.

Peninsular Supply Co., Fort Laudredale, Fla. (in principle).

Piers, Eber F., Ogden, Utah.

Pitt \& Co., Walter A., Bloomfield, N. J.

Pleasantville Plumbing Supply Co. (Inc.), Pleasantville, N. J.

Plumbers' Supply Co., New Bedford, Mass.

Porcelain Enamel \& Manufacturing Co., Baltimore, $\mathrm{Md}$.

Processed Minerals Co., Washington, D. C. (in principle).

Providence Plumbing Supply Co., Providence, R. I. (in principle).

Puritan Sanitary Supply Co. (Ine), Cambridge, Mass.

Rainear \& Co., C. J., Philadelphia, Pa.

Rayl Co., The, Detroit, Mich.

Reichle Supply Co., Saginaw, Mich.

Resolute Pottery Co., Trenton, N. J.

Richmond Radiator Co., New York, N. Y.

Richmond Sanitary Co., San Francisco, Calif.

Roberts \& Bro., J. T., Baltimore, Md.

Roberts Hamilton Co., Minneapolis, Minn.

Rockford Plumbing Supply Co., Rockford, Ill. 


\section{SC.OPE}

This standard designates colors (fig. 1.) to be used as a guide in production of sanitary ware, plumbing fixtures, and allied products made of vitreous china, porcelain (all-clay) enameled iron, metals, wood, or glass.

The development of individual colors for special pieces-for instance, drinking fountains-and the matching of colors for special work will not come within the scope of this commercial standard.

\section{PURPOSE}

Manufacturers of colored sanitary ware have encountered problems due to the multiplicity of colors that are expensive to manufacture, impracticable to stock, and unsatisfactory to sell. The increasing variety of colors has resulted in a lack of harmony, especially when one manufacturer supplies the vitreous china lavatory, another the enameled iron bathtub, and still another the seat for the water-closet bowl. This standard is offered as a solution of these problems.

It is not the purpose of this standard to retard initiative on the part of the individual producers or to limit the introduction of new colors, but it is intended to provide an authoritative record of the recommendation of the industry as a whole based on composite experience.

\section{GENERAL}

The following requirements are necessary for the successful coordination of individual color ranges in products made from vitreous china, porcelain (all-clay), enameled iron, and allied materials.

The colors must be (1) desirable, agreeable, and pleasing from the purchaser's viewpoint; (2) economically produced; (3) easily reproduced; (4) suitable to enameled cast iron, vitreous china, porcelain (all-clay), glass, and wood from a technical as well as from a sales standpoint; and (5) limited in number.

In the standardization of colors for sanitary ware it should be borne in mind that an absolute match of colors is neither possible nor necessary, but the colors should match as nearly as the differences in the character of materials, lighting conditions, and manufacturing processes permit. Perhaps the most difficult problem to contend with in color matching arises in trying to match one type of colored surface with another of an entirely different texture.

Factors involved in determining the color ascribed to the flat uniform, isotropic surface of an opaque object are as follows:

1. The quality, spectral distribution, or color composition of light which falls on the surface.

2. The illumination (amount of light which falls on the surface in unit time).

3. Polarization of the incident light.

4. The mode of incidence; that is, the direction or directions from which the light comes. (If the object is receiving light from more than one source, primary or secondary, the situation becomes very complex.)

5. The angle between the normal to the surface and the direction from the eye to the surface. 
GREEN SC-11

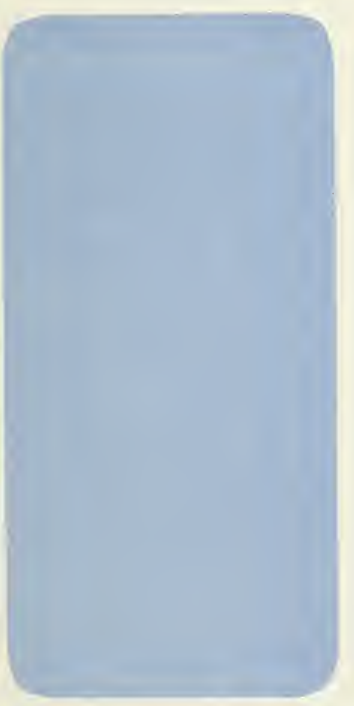

BLUE SC-40

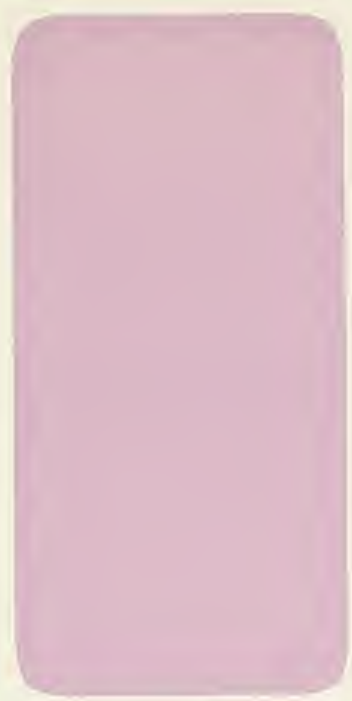

ORCHID SC-20

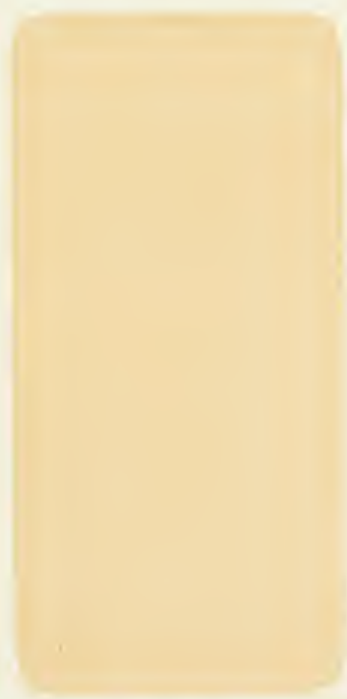

LIGHT BROWN SC-51
IVORY SC-30

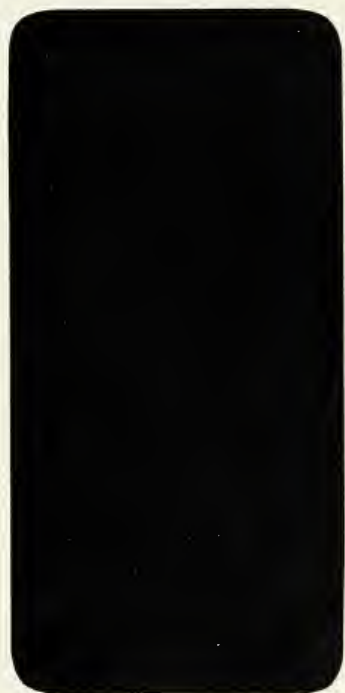

BLACK SC-60

\section{Figure 1.-Colors for Sanitary Ware}

NotE.-The reproductions shown herein are intended only to indicate the colors selected by the industry. For production and sales purposes, duplicate standard color reference samples may be obtained as explained under "Detail requirements." 

6. The solid angle subtended at the observer's eye by the surface.

7. Neighboring objects in the field of view.

8. The state of adaptation of the eye.

9. Various characteristics of the observer.

10. The position of the object in the field of view.

11. The object itself. (a) The material of which the object is made. (b) The nature and condition of the surface which is viewed.

Certain coloring material possess qualitites that alter their appearance under different conditions of production.

Daylight is usually considered white and is the proper type of illumination under which colors should be examined. Daylight, however, is variable throughout the day. Colors that match in natural light are often different when compared under artificial light. Colorists have more or less universally adopted north skylight as standard for matching colors.

\section{METHOD OF MAKING COLOR COMPARISONS}

When comparing colors of colored sanitary ware the line of observation shall be at right angles to the surface of the sample, which shall be so placed under the diffused light of a northern sky that minute shadows affecting the appearance of the colored surface will be reduced to a minimum, and the light source, reflections of lights, or differently colored surfaces should be prevented from being mirrored in the gloss of the sample.

The two surfaces to be compared shall be covered by a mask of neutral gray paper at least 8 inches square, with a rectangular opening $1 \frac{1}{2}$ by 4 inches cut in its center. The exposed area of each surface shall be approximately $1 \frac{1}{2}$ by 2 inches. The purpose of the mask is to conceal the surrounding colors, to bring into immediate focus the single color to be examined, and to restrict the area of the fixture to that of the color sample with which it is compared.

The normal recovery of the eye from the natural fatigue occurring by examining colors is distinctly rapid. Nevertheless, some time should be permitted to elapse between making successive comparisons.

No attempt should be made to match colors from memory.

\section{DETAIL REQUIREMENTS}

The six colors recommended as standard colors for sanitary ware shall be designated as follows:

$$
\begin{array}{ll}
\text { SC-11, green. } & \text { SC-40, blue. } \\
\text { SC-20, orchid. } & \text { SC-51, light brown. } \\
\text { SC-30, ivory. } & \text { SC-60, black. }
\end{array}
$$

The standard color samples shall be retained at the National Bureat of Standards. Duplicate reference color samples may be obtained at a cost of $\$ 1.50$ per set from the secretary ${ }^{1}$ of the Manufacturers' Advisory Committee on Colors for Sanitary Ware as a basis for production control. The manufacturers' advisory committee has fixed light and dark limits for each color, and samples are to be retained at the National Bureau of Standards. Such samples will be available only for the settlement of disputes. While any color within these limits will no doubt conform with the requirements, it is understood

1 G. W. Wray, National Bureau of Standards, Washington, D. C.

$71015^{\circ}-32--2$ 
that every effort will be made to conform as nearly as possible to the reference color samples.

The color of sanitary ware shall be considered to match the standard color sample when, on comparison of the ware with a duplicate reference color sample under the specified lighting conditions and by the specified method, there is no appreciable difference in color.

The advisory committee recommends that secrecy in connection with the subject of colored glazes and enamels be eliminated. In. order that manufactureres may have a thorough understanding concerning colored glazes the formulas, firing temperatures, and other pertinent information have been filed with the National Bureau of Standards, and are available upon request.

It is recommended that all colored sanitary ware shall be considered as special rather than staple owing to the number of different types and shapes and the cost involved in stocking such a variety.

\section{HISTORY OF PROJECT}

At a meeting of the Manufacturers' Advisory Committee on Vitreous China Plumbing Fixtures held in Washington April 25, 1928, a committee with W. Keith McAfee as chairman was appointed to consider standardization of colors for sanitary ware. This committee met in Washington June 29, 1928, to discuss problems arising from the introduction of color in the manufacture of sanitary ware. A joint technical committee, with members from the vitreous china and enameled iron industries met in Pittsburgh in September, 1928, and proposed five colors-green, orchid, blue, ivory, and light brown-as being suitable for use on vitreous china and cast-iron enameled ware. However, the exact shades were not decided upon. The report of the color committee was presented to meetings of the Manufacturers' Advisory Committee on Vitreous China Plumbing Fixtures held in Washington September 26, 1928, and May 2, 1929, and was received without final action. The standardization of color was again brought up for discussion at a meeting of the Manufacturers' Advisory Committee on Vitreous China Plumbing Fixtures held in Washington September 25, 1929. The secretary was authorized to request samples, and as a result of this request 104 different shades were received from 7 manufacturers of vitreous china and 13 manufacturers of enameled iron plumbing fixtures.

At a joint committee meeting of the Manufacturers of Vitreous China and Enameled Iron Plumbing Fixtures held in Pittsburgh March 14, 1930, six colors were selected from the samples submitted by the manufacturers as proposed standard colors for colored sanitary ware as follows: Green, orchid, blue, ivory, brown, and black. It was voted at this meeting that the standardization of colors for plumbing fixtures be made a separate project to be carried on in cooperation with the division of trade standards, National Bureau of Standards.

A preliminary conference of the manufacturers of enameled iron and vitreous china plumbing fixtures was held March 25, 1930, in Chicago. An advisory committee was formed which appointed an executive committee. The six colors selected at the previous meeting were indorsed, but were declared as being of such shades as to offer manufacturing difficulties. Accordingly different shades of the same colors were selected as being better from a manufacturing point of view and 
were designated as follows: SC-10, green; SC-20, orchid; SC-30, ivory; SC-40, blue; SC-50, brown; and SC-60, black.

Samples for experimental purposes were prepared for distribution to manufacturers desiring them through the secretary of the Manufacturers' Advisory Committee on Colors for Sanitary Ware for $\$ 1.50$ per set. The SC-10, green and SC-50, brown, were found to involve manufacturing difficulties, especially to the producers of vitreous china plumbing fixtures.

To overcome these manufacturing difficulties new shades of green and brown, designated as SC-11 and SC-51, respectively, were selected by the advisory committee to replace the SC-10 and SC-50. Following experimental production trials, the Manufacturers' Advisory Committee on Colors for Sanitary Ware then presented the recommendations for standard colors for colored sanitary ware to the National Bureau of Standards with a request that a general conference be called of the producers, distributors, and users of this commodity.

\section{GENERAL CONFERENCE}

In compliance with a request from the Manufacturers' Advisory Committee on Colors for Sanitary Ware a general conference of producers, distributors, and users of this commodity was held at the National Bureau of Standards, Washington, D. C., January 23, 1931, to consider the adoption of six standard colors to be used as a guide in the production and purchase of sanitary ware, including plumbing fixtures and allied products made of vitreous china, porcelain (all-clay), enameled iron, metals, wood, or glass. The following individuals were present:

Baldwin, H. C., R. \& H. Chemical Co., Perth Amboy, N. J.

Barrett, Robert J., National Association of Master Plumbers, Washington, D. C.

BEACOCK, LEwis E., Bureau of the Census, Washington, D. C.

Berryman, P. R., Trenton Potteries Co., Trenton, N. J.

CoLE, H. R., Tile \& Mantel Contractors Association, Washington, D. C.

Fairchild, I. J., National Bureau of Standards, Washington, D. C.

Geller, R. F., National Bureau of Standards, Washington, D. C.

Harrison, W. N., National Bureau of Standards, Washington, D. C.

Herr, Horace H., Ceramic Industry Magazine, Washington, D. C.

Jordan, R. E., The Mosaic Tile Co., New York, N. Y.

Langenbeck, Karl, Processed Minerals Co., Washington, D. C.

LangFord, W. G., Richmond Radiator Co., New York, N. Y.

Law Nin, L. D., Ưnion Sanitary Works, Noblesville, Ind. N. O. Nelson Manufacturing Co., St. Louis, Mo.

Lenchner, Theo., R. \& H. Chemical Co., New York, N. Y.

MADDOCK, A. M., Standard Sanitary Manufacturing Co., Trenton, N. J.

MaHONEY, W. T., Wolff Co., Chicago, Ill.

McAfee, W. Kmith, Universal Sanitary Manufacturing Co., New Castle, Pa.

McCurdy, G. R., Crane Co. Chicago, Ill.

McGonegal, A. R., American Society of Sanitary Engineering, Washington, D. C.

Moore, W. G., Humphreys Manufacturing Co., Mansfield, Ohio.

Picketr, Arthur D., Associated Tile Manufacturers, New York, N. Y.

Priest, I. G., National Bureau of Standards, Washington, D. C.

Simpson, James, Abingdon Sanitary Manufacturing Co., Abingdon, Ill.

Smith, Don D., Abingdon Sanitary Manufacturing Co., Abingdon, IIl.

Sodder, M. Attie, American Home Economics Association, Rockwell City, Iowa.

Weiskittel, H. J., A. Weiskittel \& Son Co., Baltimore, Md.

WraY, G. W., National Bureau of Standards, Washington, D. C.

ZeILler, I. F., B. F. Drakenfeld \& Co., New York, N. Y. 
The conference, held under the auspices of the division of trade standards, was called to order by I. J. Fairchild, who introduced Dr. George K. Burgess, Director of the National Bureau of Standards.

Doctor Burgess welcomed the members of the conference to the National Bureau of Standards and reviewed briefly the history of the divisions of simplified practice and trade standards. He stated that, according to the Bureau of the Census, the total value of enameled iron, vitreous china, and porcelain fixtures, exclusive of fittings, produced in 1929, was $\$ 72,615,190$. Although no authentic information as to the proportion of this amount represented by colored ware is available, it is believed that, in view of the cost of installation, handling and shipment, the waste from lack of color standards is out of proportion to the total value of production, as compared to other commodities. The director further stated that the standardization of colors for bathroom equipment is of particular interest at this time not only because of the growing appreciation and use of colors in bathrooms, but as a possible means of solving similar color problems in allied industries. He expressed the hope that the conference would arrive at a mutually agreeable solution of the existing confusing problems in the industry.

Mr. Fairchild outlined the procedure for the development of commercial standards and the function of the Department of Commerce in the procedure.

Mr. W. Keith McAfee, chairman of the manufacturers' advisory committee, presented the proposed commercial standard for the manufacturers' advisory committee, and outlined its purposes in establishing standard colors for sanitary ware, the principal reason being to correct the lack of color harmony due to the large variety of colors with the inevitable necessity of matching colors of competing manufacturers. He emphasized the fact that with the standard colors definitely recorded and readily available for reference, a medium will be provided whereby the manufacturer may certify a standard color to the consumer or whereby the buyer may check the color of bathroom equipment as received from the seller, with a consequent reduction of avoidable waste and an attendant improvement in marketing conditions.

Mr. Wray read a number of letters from companies which could not be represented, favoring the adoption of the standard colors as proposed by the advisory committee.

The proposed commercial standard dated January 3, 1931 was then considered seriatim in connection with suggestions from the conferees. Mr. Lawnin, president of the N. O. Nelson Manufacturing Co., and R. E. Jordan, vice president of the Mosaic Tile Co., expressed themselves as being in hearty accord with the movement.

As a result of the discussion, a few minor revisions were agreed upon by the conference and upon motion by Mr. McAfee, seconded by Mr. Simpson it was voted to adopt the recommended commercial standard as a whole, subject to the authorized corrections.

\section{STANDING COMMITTEE}

The conference appointed W. Keith McAfee as chairman of a standing committee and requested him to appoint other members to represent the producers, distributors, and users on this committee 
to consider the necessity for, and suggestions pertaining to, the revision of the standard in order that it might be kept abreast with progress in the industry and with the demands of purchasers for new colors. The chairman, in consultation with interested organizations, made the required appointments, with the result that the following constitute the membership:

W. Keith McAfee, Chairman, Universal Sanitary Manufacturing Co.

James Simpson, Abingdon Sanitary Manufacturing Co.

A. G. Zibelle, Kohler Co.

J. L. Campbell, C. F. Church Manufacturing Co. (Division of Standard Sanitary Manufacturing Co.).

H. R. Cole, The Tile and Mantel Contractors Association.

W. J. Spillane, Jas. B. Clow \& Sons.

R. J. BARRETT, National Association of Master Plumbers.

Benjamin CADBURY, Hajoca Corporation.

F. LeO Smith, American Institute of Architects.

Miss M. Attie Souder, American Home Economics Association.

A. R. McGonegal, Inspector of Plumbing, Washington, D. C.

G. W. WraY, ex officio secretary, National Bureau of Standards.

\section{EFFECTIVE DATE}

The effective date for new production and for clearance of existing stocks under the commercial standard was fixed as of July 1, 1931, with a revision interval of one year.

\section{CERTIFICATION PLAN}

The conference voted its approval of the certification plan for application to colors for sanitary ware in accordance with the commercial standard.

The certification plan as applied by the National Bureau of Standards to commercial standards consists in the compilation and distribution of lists of manufacturers who are willing, when requested to do so, to certify to purchasers that products supplied by them comply with all the requirements and tests set forth in nationally recognized commercial standards. The plan is also applied to selected Federal specifications.

These lists are available on request to individual consumers, consumer groups, companies, and, in fact, to any prospective purchasers, for their guidance.

The benefits now derived from the use of specifications by large consumers are thus made immediately available to the small consumer, with incidental advantage to the larger consumers of convenience in ordering and accepting material with fewer laboratory tests. The manufacturer also benefits from the well-known economies accompanying "mass production."

The lists of manufacturers "willing-to-certify" to the quality of certain commodities are made by corresponding with, as nearly as possible, all the manufacturers of that product and listing only those who signify their willingness to certify to the purchaser, when requested to do so, that the commodities delivered actually comply with the commercial standard.

Obviously, the purchaser making use of the lists of "willing-tocertify" manufacturers, will select therefrom such manufacturers as are known (or assumed) by him to be reliable. 
The trend toward the purchase of materials of certified quality from sources shown on such willing-to-certify lists supplied added incentive to standardization on the part of other producers, and thus the benefits of the certification plan will be felt by purchasers either directly or indirectly, whether or not they make use of the plan themselves.

\section{COMMERCIAL STANDARDS SERVICE}

\section{INTRODUCTION}

Industry has long sensed the need for a wider application and use of specifications developed and approved by nationally recognized organizations. To assist these bodies and the producers and consumers in securing this result and as a natural outgrowth of the movement toward elimination of waste through simplified practice, the National Bureau of Standards has set up a procedure under which specifications, properly indorsed, may be printed as official publications of the Department of Commerce and promulgated as "commercial standards." This service parallels that of simplified practice in many respects and is available only upon request.

Broadly speaking, the aim is to continue the same character of cooperative service in this field that is being rendered in simplification. The division of trade standards is not designed to act as a standardizing body, nor will it engage in the preparation of specifications. Its service is mainly promotional in character, since its chief mission is to invite attention to a standard or a specification which any branch of industry may want to promulgate on a nation-wide basis; to determine its eligibility for promulgation; to publish and broadcast it in the event the prerequisites of procedure have been met, including a satisfactory majority acceptance; to facilitate the application of the certification plan for the assurance and convenience of the purchaser; to provide means for periodic audits of adherence; and to cooperate with the Bureau of Foreign and Domestic Commerce in determining: the desire of industry relative to translation and promulgation of such specifications as a basis for foreign commerce.

In general, it may be said that a simplification covers types, sizes, and varieties of a commodity which are retained by industry on the basis of demand, whereas a commercial standard establishes definite requirements as to grade, quality, or dimensional tolerances in addition to any limitation of variety desired and accepted by the industry.

\section{ORGANIZATION AND DUTIES OF STANDING COMIMITTEE}

In order to carry on the aims and desires of the industry in the standardization of their product, a standing committee is appointed at the general conference. This committee consists of members from each division of the industry, namely, producers, distributors, and consumers, and thus reflects the well-balanced viewpoint of all concerned.

The members of the committee receive all suggestions regarding the commercial standard and consider its revision in the event that such action is desirable and mutually beneficial. 
If the commercial standard does not warrant revision, it is reaffirmed in its existing form, but if any important changes are found desirable, their adoption is recommended by the committee, whereupon the industry is again solicited for written acceptance of the standard in its revised form.

The committee is in effect a centralizing agency for criticisms and comments regarding the commercial standard and is charged with the responsibility of recommending revisions to keep the standard abreast with current industrial practice.

The proper functioning of the committee requires that, when necessary, its members be willing to attend meetings held at some central place, although in many cases it will be possible to conduct the work by correspondence.

When any deceptions in reference to the commercial standard are reported to the standing committee, it applies moral suasion or such other corrective measures as seem desirable. The Department of Commerce has no "police power" to compel adherence, therefore it is incumbent upon the standing committee to do all in its power to encourage all divisions of the industry to follow the provisions of the commercial standard and contribute in every way possible to its general adoption and usefulness.

\section{YOUR COOPERATION}

As a producer, distributor, or consumer of some of the commodities for which commercial standards have already been established, you are in a position to avail yourself of the benefits arising from the use of quality standards and incidentally to add impetus to this method of eliminating waste.

The first step is a declaration in favor of the standard by recording your intention to adhere, as closely as circumstances will allow, to the standards for those products which you may buy or sell.

The receipt of your signed acceptance will permit the listing of your company in new editions of the commercial standards that you accept.

You will, of course, want to examine any commercial standards before signing a formal acceptance. The National Bureau of Standards will, therefore, furnish a copy of any standard under consideration for acceptance. A list of current commercial standards is given on the rear cover. The publications may also be secured singly or in quantities at a nominal price from the Government Printing Office. Prices will be furnished upon request.

The acceptance of a commercial standard is an entirely voluntary action and applies to the production, sale, and use of stock items. It is not meant to interfere with the introduction, manufacture, or sale of special sizes and types sometimes required.

Trade associations and individual companies often distribute large numbers of the printed standard for the information and guidance of their members or customers. In such cases it is possible to extend the scope and degree of adherence by urging each recipient to send in an acceptance, bearing in mind that the practical value of any standardization is measured by the observance it receives.

An acceptance form for the commercial standard herein covered is included on page 10. 


\section{ACCEPTANCE OF COMMERCIAL STANDARD}

\section{Please sign and return this sheet to Division of Trade Stand-} ards, National Bureau of Standards, Washington, D. C.

Division of Trade Standards,

$$
\text { Date }
$$

\section{National Bureau of Standards,}

$$
\text { Washington, D.C. }
$$

Gentlemen: We the undersigned, do hereby accept the original draft of the commercial standard as our standard practice in the $\left\{\begin{array}{l}\text { production }^{1} \\ \text { distribution }^{1} \\ \text { use }^{1}\end{array}\right\}$ of colored sanitary ware beginning -..............., and will use our best effort in securing its general adoption.

To permit intelligent review of the effectiveness of the commercial standard every year by an accredited committee of all interests, working in cooperation with the Department of Commerce, we plan to supply all data, upon request, which may be necessary for the development of constructive revisions. It is understood that any suggested modifications will be submitted as soon as formulated and shall not be promulgated until accepted in form similar to this recommendation.

Signature

(Kindly typewrite or print the following lines).

Title

Company

Street address

City and State

We are members of the following associations or other organizations interested in the production, sale, or use of colored sanitary ware.

1 Please designate which group you represent by drawing lines through the other two. In the case of related interests, trade papers, colleges, etc., desiring to record their general approval, the words "in principle" should be added after the signature. 


\section{TO THE ACCEPTOR}

In signing the acceptance blank please bear the following points clearly in mind:

1. Adherence.-The Department of Commerce has no regulatory powers to enforce adherence to the commercial standards. Instead, this waste-elimination program is based on voluntary cooperation and self-government in industry. To make this specific standardization operate as a satisfactory example of self-government, it is highly desirable that it be kept distinct from any plan or method of governmental regulation or control. It will be successful according to the degree to which manufacturers, distributors, and purchasers adhere to its terms and conditions.

2. The industry's responsibility.-The department cooperates only on the request of the industry and assumes no responsibility for industrial acceptance or adherence. This program was developed by the industry on its own initiative. Its success depends wholly on the active cooperation of those concerned.

3. The acceptor's responsibility.- You are entering into an entirely voluntary arrangement, whereby the members of the industry-the distributors and consumers of the product and others concernedhope to secure the benefits inherent in commercial standardization. Those responsible for this standard realize that instances may occur in which it will be necessary to supply or purchase items not included therein. The purpose is, however, to secure wider support for nationally recognized standards covering grade, quality, and other characteristics of products. Consumers can make the program a success if, in their purchasing, they will make a definite and conscientious effort to specify in terms of this commercial standard.

4. The department's responsibility.-The function performed by the Department of Commerce is fourfold: First, to act as a referee to insure adequate consideration of the needs of all interests; second, to supply such assistance and advice in the development of this program as past experience with similar programs may suggest; third, to solicit and record the extent of adoption and adherence to the standard; and, fourth, to add all possible prestige to this standardization movement by publication and promulgation if and when it is adopted and accepted by all elements directly concerned. 





\section{COMMERCIAL STANDARDS}

CS. No.

0-30. The commercial standards service and its value to business.

1-28. Clinical thermometers.

2-30. Mopsticks.

3-28. Stoddard solvent.

4-29. Staple porcelain (all-clay) plumbing fixtures.

5-29. Steel pipe nipples.

6-31. Wrought-iron pipe nipples (first revision)

7-29. Standard weight malleable iron or stee screwed unions.

8-30. Plain and thread plug and ring gage blanks.

9-29. Builders' template hardware.

10-29. Brass pipe nipples.

11-29. Regain of mercerized cotton yarns.

12-29. Domestic and industrial fuel oils.

13-30. Dress patterns.

14-31. Boys' blouses, button-on waists, shirts, and junior shirts.

15-29. Men's pajamas.

16-29. Wall paper.

17-30. Diamond core drill fittings.
CS. No.

18-29. Hickory golf shafts.

19-30. Foundry patterns of wood.

20-30. Staple vitreous china plumbing fixtures.

21-30. Interchangeable ground glass joints.

22-30. Builders' hardware (nontemplate).

23-30. Feldspar.

24-30. Standard screw threads.

25-30. Special screw threads.

26-30. Aromatic red cedar closet lining.

27-30. Plate glass mirrors.

28-32. Cotton fabric tents, tarpaulins, and covers.

29-31. Staple seats for water-closet bowls.

30-31. Colors for sanitary ware.

31-31. Red cedar shingles (in preparation)

$32-31$. Cotton cloth for rubber and pyroxylin coating (in preparation).

33-32. Knit underwear (exclusive of rayon) (in preparation).

34-31. Bag, case, and strap leather (in preparation). 35-31. Plywood (in preparation).

36-31. Fourdrinier wire cloth (in preparation).

Notice.-Those interested in commercial standards with a view toward accepting them as a basis of every day practice in their industry, may secure copies of the above standards, while the supply lasts, by addressing the Division of Trade Standards, National Bureau of Standards, Washington, D. C. 
